\title{
SEX CHROMATIN FORMATION IN THE BLASTOCYST OF THE ROE DEER (CAPREOLUS CAPREOLUS) DURING DELAYED IMPLANTATION
}

\author{
R. J. AITKEN* \\ Department of Veterinary Clinical Studies, School of Veterinary Medicine, \\ Madingley Road, Cambridge CB3 OES
}

(Received 17th April 1974)

According to the Lyon hypothesis (Lyon, 1961, 1972), random genetic inactivation of one of the two $\mathrm{X}$ chromosomes occurs in the somatic cells of female mammals at an early stage of embryonic development. Certain properties of this inactivated chromosome, such as its late replication during the S-phase of mitosis (Taylor, 1960; Grumbach \& Morishima, 1962; Mukherjee \& Sinha, 1963), heteropyknosis during prophase and the formation of a sex chromatin body during interphase (Ohno, Kaplan \& Kinosita, 1959; Ohno \& Hauschka, 1960) have been used as criteria for establishing when the process of inactivation begins. These features first appear in blastocysts at about the time of implantation in the cat (Austin \& Amoroso, 1957), dog (Austin, 1966), rat (Zybina, 1960), hamster (Hill \& Yunis, 1967), vole (Microtus agrestis) (Lee \& Yunis, 1971), rhesus monkey (Macaca mulatta) (Park, 1957) and man (Glenister, 1956; Park, 1957). Gardner \& Lyon (1971) used X-linked markers to show that Xinactivation had already occurred in some cells obtained from $3 \frac{1}{2}$-day mouse blastocysts before implantation and transferred to host embryos of the same age. In the rabbit (Melander, 1962; Issa, Blank \& Atherton, 1969; Plotnick, Klinger \& Kosseff, 1971) and pig (Axelson, 1968), sex chromatin formation occurs even earlier, during the morula-blastocyst transition phase. Furthermore, Issa et al. (1969) discovered that a late replicating $\mathrm{X}$ chromosome can be identified in rabbit morulae about $24 \mathrm{hr}$ before the first appearance of sex chromatin; hence, the formation of sex chromatin may be a secondary phenomenon, occurring some hours after $\mathrm{X}$ inactivation.

An analysis of the factors controlling the onset of sex chromatin formation in the rabbit (Klinger, Kosseff \& Plotnick, 1971) suggested that absolute time from fertilization was the most important single factor, although a lowering of cell metabolism may also be involved (Klinger, Davis, Goldhuber \& Ditta, 1968; Issa et al., 1969). It was, therefore, of interest to study the formation of sex chromatin during the development of a species such as the roe deer in which the blastocyst is maintained unattached and metabolically inactive in the uterine lumen for about 5 months (Short \& Hay, 1966; Aitken, Burton, Hawkins, Kerr-Wilson, Short \& Steven, 1973).

This study was based upon the analysis of thirty blastocysts and five elonga-

* Present address: Department of Genetics, West Mains Road, Edinburgh EH9 3JN. 
ting embryos flushed from the uteri of thirty roe deer shot during the annual Forestry Commission cull at Thetford Chase, Norfolk. Whenever possible, the diameter of blastocysts was measured at the time of recovery, before they had started to collapse. The embryos were quickly removed from the flushing medium $(0.85 \%$ phosphate-buffered saline), fixed in methanol and prepared as flat mounts (Moog \& Lutwak-Mann, 1958) for staining by the Feulgen or acetoorcein technique. The frequency of sex chromatin-positive cells was assessed by scoring at least 100 cells in each embryo; all observations were confined to the trophoblast since little nuclear detail could be distinguished within the inner cell mass of flat mount preparations.

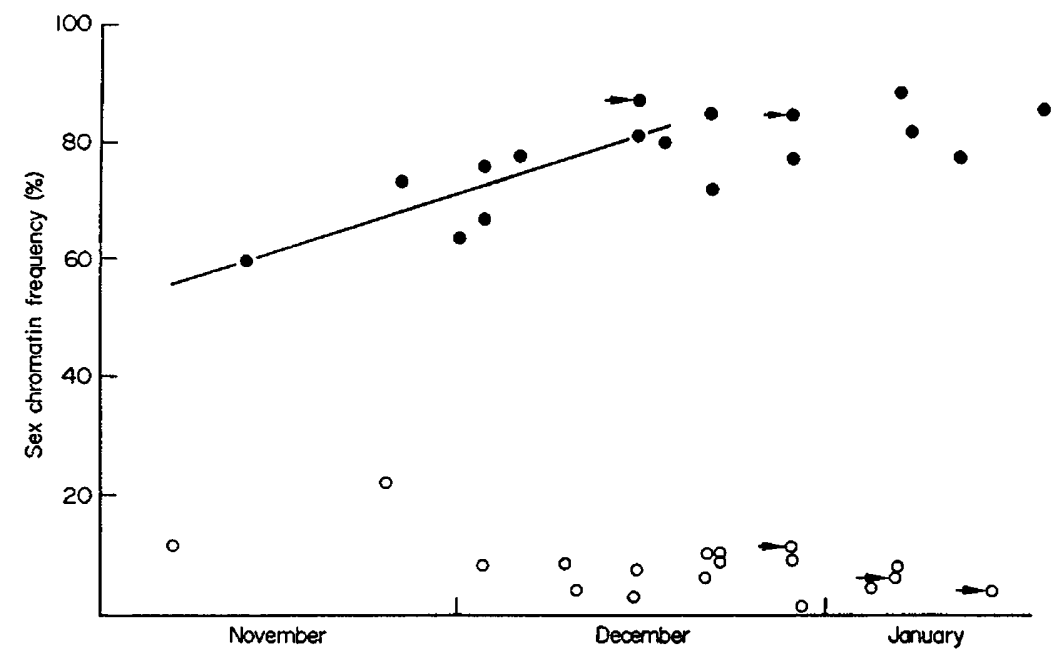

TEXT-FIG. 1. Frequency of sex chromatin-positive cells in roe deer blastocysts recovered during delayed implantation. $O$, Presumptive males; $\bullet$, presumptive females. Arrows indicate rapidly elongating embryos. A regression line describing the relationship between sex chromatin frequency and recovery date $(12$ th November $=1)$ for the first nine blastocysts is given by the formula $y=58 \cdot 3+0 \cdot 67 x$, the correlation being highly significant $(r=0.85, P<0.001)$.

The results of this investigation revealed that the embryos could be divided into two distinct groups on the basis of nuclear morphology (Text-fig. 1). In one group, the presumptive females, a large chromatin condensation resembling the sex chromatin body was observed in a majority of the trophectoderm, and some trophendoderm, cell nuclei. The sex chromatin was normally spherical, U-, or $\mathrm{V}$-shaped and was located adjacent to the nuclear membrane, free in the nucleoplasm or in association with the nucleoli. The mean percentage frequency of sex chromatin-positive cells for all presumptive female embryos was $77 \cdot 2 \pm 8.3 \%$ (mean \pm S.D.). If only those nuclei possessing a sex chromatin body adjacent to the nuclear membrane were scored as positive, the average frequency would have been about $51 \%$ (examination of 3000 nuclei from five blastocysts revealed that in $65 \%$ of the positively scored cells the sex chromatin was associated with the nuclear membrane). The results presented in Text-fig. 1 also suggested that the sex chromatin frequency was still increasing amongst blastocysts recovered before the 2nd week in December; after this date, the values appeared to level 
off. Hence, the frequency observed before 10 th December $(69 \cdot 1 \pm 7 \cdot 1 \%$; mean \pm S.D. $)$ was significantly lower $(P<0.001)$ than the mean observed after that date $(81.6 \pm 5.7 \%$; mean \pm S.D. $)$. A positive correlation $(P<0.01 ; r=0.87)$ was also observed between the frequency of sex chromatin and the diameter of six presumptive female blastocysts (Table 1).

In the second group of embryos, the presumptive males, large condensations of chromatin resembling sex chromatin were only observed in $7 \cdot 6 \pm 4.5 \%$ (mean $\pm S . D$.) of the cells. In most of the nuclei, fine particles of chromatin could be seen and although they were often associated with the nuclear membrane or nucleoli, these condensations were much smaller than the sex chromatin of female embryos.

On the basis of nuclear morphology, the thirty-five embryos examined could be divided presumptively into eighteen males and seventeen females, which is not significantly different from the expected $1: 1$ sex ratio.

Table 1. The relationship between the diameter and sex chromatin frequency of roe deer blastocysts

\begin{tabular}{c|c|c}
\hline $\begin{array}{c}\text { Date of blastocyst } \\
\text { recovery }\end{array}$ & $\begin{array}{c}\text { Greater diameter } \\
\text { of blastocyst }(\mathrm{mm})\end{array}$ & Sex chromatin frequency (\%) \\
\hline 12th November & $1 \cdot 0$ & $59 \cdot 5$ \\
25th November & $1 \cdot 7$ & $72 \cdot 5$ \\
2nd December & $2 \cdot 2$ & $66 \cdot 7$ \\
17th December & $2 \cdot 4$ & $79 \cdot 6$ \\
21 st December & $4 \cdot 8$ & 84.5 \\
6th January & 9.9 & $88 \cdot 6$ \\
\hline
\end{tabular}

Since the roe deer has an 'original' type of $\mathrm{X}$ chromosome (Gustavsson \& Sundt, 1968), it is unlikely that the nuclear condensations observed were of constitutive chromatin such as appears during the cleavage stages of mammals with composite X chromosomes (Hill \& Yunis, 1967; Lee \& Yunis, 1971) and hence the presence of sex chromatin presumably represents $\mathrm{X}$ chromosome inactivation. The results indicate that the frequency of sex chromatin-positive cells increases slowly during delayed implantation, reaching a maximum of about $82 \%$ in the middle of December, by which time the blastocyst is about 5 months old; in contrast, 85 to $90 \%$ of rabbit blastocyst cells are sex chromatinpositive by $140 \mathrm{hr}$ post coitum (Klinger et al., 1971). The gradual formation of sex chromatin in the roe deer blastocyst during diapause may be due to the low rate of cell division at this time; only one dividing cell/1000 can be detected in the roe deer blastocyst at the beginning of December (R. J. Aitken, unpublished observations) compared with a figure of $11 / 100$ in the preimplantation rabbit blastocyst (Moog \& Lutwak-Mann, 1958). The formation of sex chromatin during diapause also infers that this process can occur in the absence of the endometrial secretions, which are not released into the uterine lumen until the resumption of rapid embryonic growth in January (Aitken et al., 1973; Aitken, 1974). The irrelevance of specific maternal factors in the initiation of $X$ chromosome inactivation is also suggested by the fact that sex chromatin formation 
occurs during the culture in vitro of rabbit (Klinger et al., 1971) and mouse (De Mars, 1967) embryos.

The roe deer seems to be similar to the rabbit and pig, therefore, in that sex chromatin formation occurs well before implantation. These preliminary results suggest a need for further studies to establish the time at which sex chromatin first appears in this species and its relation to the onset of embryonic diapause. The possibility also arises of using the roe deer blastocyst as a model for investigating the relationship between sex chromatin formation and changes in cell number, cell density and cell division, all of which show a gradual increase during the 5 months of delayed implantation.

This work was carried out while the author was in receipt of an M.R.C. Research Studentship. Grateful thanks are due to Dr R. V. Short for his help and encouragement throughout this study and to Dr M. F. Lyon for her valuable criticism of the manuscript.

\section{REFERENGES}

Aitken, R. J. (1974) Delayed implantation in roe deer (Capreolus capreolus). F. Reprod. Fert. 39, 225.

Aitken, R. J., Burton, J., Hawkins, J., KerR-Wilson, R., Short, R. V. \& Steven, D. H. (1973) Histological and ultrastructural changes in the blastocyst and reproductive tract of the roe deer (Capreolus capreolus) during delayed implantation. F. Reprod. Fert. 34, 481.

Austin, G. R. (1966) Sex chromatin in embryonic and fetal tissues. In The Sex Chromatin, p. 241. Ed. K. L. Moore. Saunders, Philadelphia.

Austin, C. R. \& Amoroso, E. C. (1957) Sex chromatin in early cat embryos. Expl Cell Res. 13, 419.

Axeison, M. (1968) Sex chromatin in early pig embryos. Hereditas, 60, 347.

De Mars, R. (1967) The single-active-X: functional differentiation at the chromosome level. Natn. Cancer Inst. Monogr. 26, 327.

GARDNer, R. L. \& LyON, M. F. (1971) X-chromosome inactivation studied by injection of a single cell into the mouse blastocyst. Nature, Lond. 231, 385.

Glenister, T. W. (1956) Determination of sex in early human embryos. Nature, Lond. 177, 1135.

Grumbach, M. M. \& Morishima, A. (1962) Sex chromatin and the sex chromosomes: on the origin of sex chromatin from a single X chromosome. Acta cytol. 6, 46.

Gustavsson, I. \& Sundr, T. (1968) Unpublished observations. Gited in: Fraccaro, M., Gustavsson, I., Hultén, M., Lindsten, J. \& Tiepolo. L. (1968) Ghronology of DNA replication in the sex chromosomes of the reindeer (Rangifer tarandus L). Cytogenetics, 7, 196.

Hill, R. N. \& Yunis, J. J. (1967) Mammalian X-chromosomes: change in pattern of DNA replication during embryogenesis. Science, N.Y. 155, 1120.

Issa, M., Blank, G. E. \& Atherton, G. W. (1969) The temporal appearance of sex chromatin and of the late replicating $\mathrm{X}$ chromosome in blastocysts of the domestic rabbit. Cytogenetics, 8, 219.

Klinger, H. P., Davis, J., Goldhuber, P. \& Ditta, T. (1968) Factors influencing mammalian X chromosome condensation and sex chromatin formation. $\mathrm{I}$. The effect of in vitro cell density on sex chromatin frequency. Cytogenetics, 7, 39.

Klinger, H. P., Kossefr, A. L. \& Plotnick, F. (1971) Sex chromatin formation and RNA and protein synthesis during preimplantation development of the rabbit. Adv. Biosci. 6, 207.

LEE, J. G. \& YUNIS, J. J. (1971) A developmental study of constitutive heterochromatin in Microtus agrestis. Chromosoma, 32, 237.

Lyon, M. F. (1961) Gene action in the X chromosome of the mouse (Mus musculus L). Nature, Lond. 190, 372.

Lyon, M. F. (1972) X-chromosome inactivation and developmental patterns in mammals. Biol. Rev. 47, 1 .

Melander, Y. (1962) Chromosomal behaviour during the origin of sex chromatin in the rabbit. Hereditas, 48, 645.

Moog, F. \& Lutwak-ManN, G. (1958) Observations on rabbit blastocysts prepared as flat mounts. 7. Embryol. exp. Morph. 6, 57.

MukherJee, B. B. \& Sinha, A. K. (1963) Further studies on the pattern of chromosome duplication in cultured mammalian leucocytes. Can. F. Genet. Cytol. 5, 490. 
Ohno, S. \& HauschKa, T. S. (1960) Allocycly of the X-chromosome in tumors and normal tissues. Cancer Res. 20, 541.

Ohno, S., KAplan, W. D. \& Kinosita, R. (1959) Formation of the sex chromatin by a single X chromosome in liver cells of Rattus norvegicus. Expl Cell Res. 18, 415.

PARK, W. W. (1957) The occurrence of sex chromatin in early human and macaque embryos. F. Anat. 91, 369.

Plotnick, F., Klinger, H. P. \& Kossefp, A. L. (1971) Sex chromatin formation in preimplantation rabbit embryos. Cytogenetics, 10, 244.

Short, R. V. \& Hay, M. F. (1966) Delayed implantation in roe deer (Capreolus capreolus). Symp. zool. Soc. Lond. 15, 173.

TAYLOR, J. H. (1960) Asynchronous duplication of chromosomes in cultured cells of chinese hamster. $\mathcal{F}$. biophys. biochem. Cytol. 7, 455.

Zybina, E. V. (1960) Sex chromatin in the trophoblast of young rat embryos. Dokl. Akad. Nauk SSSR, 130,633 . 